\title{
The Development of Cooperative Type-Based Learning Media of STAD Assisted by Adobe Flash to Improve Spatial Ability of Students in Medan 1 MTs Negeri 1 Model
}

\author{
Minda Uba Manora Siregar ${ }^{1 *} \quad$ Edi Syahputra ${ }^{2} \quad$ Sriadhi $^{2}$ \\ 1.Graduate Program School in Mathematics Education, State University of Medan, Jl. Williem Iskandar Psr.V \\ Medan Estate, 20221, Sumatera Utara, Indonesia \\ 2.College Teacher State University of Medan, Jl. Williem Iskandar Psr.V Medan Estate, 20221, Sumatera Utara, \\ Indonesia
}

\begin{abstract}
In innovative learning the teacher must use learning media, because media is one of the factors that support the success of the learning process in the classroom. Through media combined with learning models, it will facilitate a conducive, creative learning process and improve learning efficiency so that learning objectives can be achieved. The purpose of this study is to develop mathematics learning media based on STAD using the Adobe Flash application program to improve students' spatial abilities. The development procedure used is a 4-D procedure. The procedure used is limited to 3-D from 4-D, namely define, design, and develop. The researcher determined the research subjects, namely class VIII-11 MTs Negeri 1 Model Medan. This study resulted in a mathematics learning media that has been declared valid and feasible to be used as a whole as a learning medium by 3 media experts who obtained an average score of 92.7 and 3 material experts who obtained an average score of 103 with each score the maximum validity is 4 . For the learning media attractiveness test stated "Very Interesting" by the group test obtaining an average score of 3.8 with each maximum score of attractiveness is 4 . While the students' spatial ability test is known the number of students who fulfill the completeness score on when the pre-test was $34 \%$, while at the post-test it was $86 \%$. So it can be concluded that the development of the STAD-based learning media produced was declared feasible and improved the spatial ability of students.
\end{abstract}

Keywords: Adobe Flash, Cooperative Learning Type STAD, Spatial Ability

DOI: $10.7176 / \mathrm{JEP} / 10-21-12$

Publication date:July $31^{\text {st }} 2019$

\section{Introduction}

Before teaching a teacher is expected to prepare the material to be taught, one of which is preparing teaching aids / labs to be used. About styles. In innovative learning the teacher must use learning media, because media is one of the factors that support the success of the learning process in the classroom. Through media, learning materials will be conveyed easily, and creative media use can facilitate and improve learning efficiency so that learning objectives can be achieved. Sinurat, syahputra, \& rajagukguk (2015) stated that with the advancement of technology today provides motivation for teachers to deliver learning material through learning media. One type of cutting-edge learning media is a computer that can be used to convey learning materials interactively and can facilitate learning because it is supported by various aspects: sound, video, animation, text, and graphics. Multimedia assisted learning such as adobe flash makes students involved and more active in learning, makes communication more effective, facilitates forums, and increases learning interest and motivation. Noviyarti, marzal, \& rohati (2015) say that by using adobe flash to develop existing learning media into a multimedia that can increase student learning interest.

Learning media tailored to the needs of creative students can be combined with cooperative learning models such as STAD. Rahmawati (2018) states that STAD learning in the form of sharing can be in the form of brainstorming, group advice, collaboration in groups, group achievements and feedback from teachers so that they can solve learning problems using media. Noviyarti, Marzal, \& Rohati (2015) also said that the development of cooperative learning-based learning media with the type of STAD assisted by adobe flash was considered suitable to be integrated.

This study aims to develop a computer program as a learning resource on gas law topics that can be used as both a learning media support in class and individual learning resource outside the class. Even though there are existing learning resources to support students in learning gas law in Indonesia, so far, we could not find comprehensive learning resource that provide complete features which are appropriate for individual learning purpose (Pratidhina, Pujianto, \& Sumardi, 2019). Some researches indicate that students' achievement increases with the use of computer by media learning in science education (Erdoğan \& Dede, 2015).

Reality in the field, especially MTs Negeri 1 Model Medan, in developing learning media, teachers pay less attention to the characteristics of the target. From the results of observations of researchers at the school, the learning media used still look less able to attract students' interest in completing them, because most are long 
stories without images or colors that can attract students to read them. The weakness of learning media in MTs Negeri 1 Medan Model is because the media developed by the teacher has not been tested for validity, practicality and effectiveness. Meanwhile, all three of these are criteria that must be met in developing learning media (Nieveen, 1999). Learning media developed by teachers have not been tested for feasibility by testing validity, effectiveness, and practicality. The development of cooperative-based learning media with the Adobe Flash-assisted STAD type is considered effective to be applied in Medan 1 Model MTs. This will be seen from the response of students in the learning process that uses learning media based on cooperative learning using the Adobe Flash-assisted STAD type. The purpose of this development is to produce new products which are improvements to existing products that can be accounted for. The improvement of this product is done because it is considered inaccurate in carrying out its functions in achieving the desired learning goals, one of which is to improve students' mathematical spatial abilities. The results of observations conducted showed that the spatial ability of students was still low. It is also stated in Syahputra (2013) that the concept of spatial thinking is many previous studies which found that children find many difficulties in understanding geometric objects or images. And cooperative learning on mathematic education approaches developed have met effective criteria and can improve mathematical spatial ability and students motivation (Putri, Hasratuddin, \& Syahputra, 2019).

In space-building learning, spatial ability plays a big role. Sari, Syahputra, \& Surya (2018) emphasize that spatial abilities are abilities related to spatial, three-dimensional numbers or definitions that are more precisely related to geometry. Subroto (2016) stated that spatial ability in mathematics education material in school is one of geometry. High spatial ability is needed for those who work in computer-graphic, engineering, and architectural fields (Kosa \& Karakus: 2010).

\section{Method}

\subsection{Research Design}

This type of research is research and development ( $R \& D)$. The development procedure used was the 4-D Thiagaradjan development model. This research was developed in the form of an Adobe-based STAD-based mathematics learning media to improve students' spatial abilities. Thiagarajan (Thiagarajan, Sammel, \& Melvyn, 1974) suggests that the steps of research and development are abbreviated as $4 \mathrm{D}$, which is an extension of Define, Design, Development, and Dissemination. In this development research, researchers used a 4-D model and only applied the steps to $\mathrm{D}$, the third was to define, design and develop because of limited time and costs. The need analysis is done by observation in class and interview with several physics teachers.

\subsection{Research Instrument}

The task and concept analysis were done by matching the material with the physics curricula in Indonesia. Based on some analysis in the define stage, we designed the computer program with Adobe Flash software (Adobe, 2009). the process of research instruments is in the picture 1:

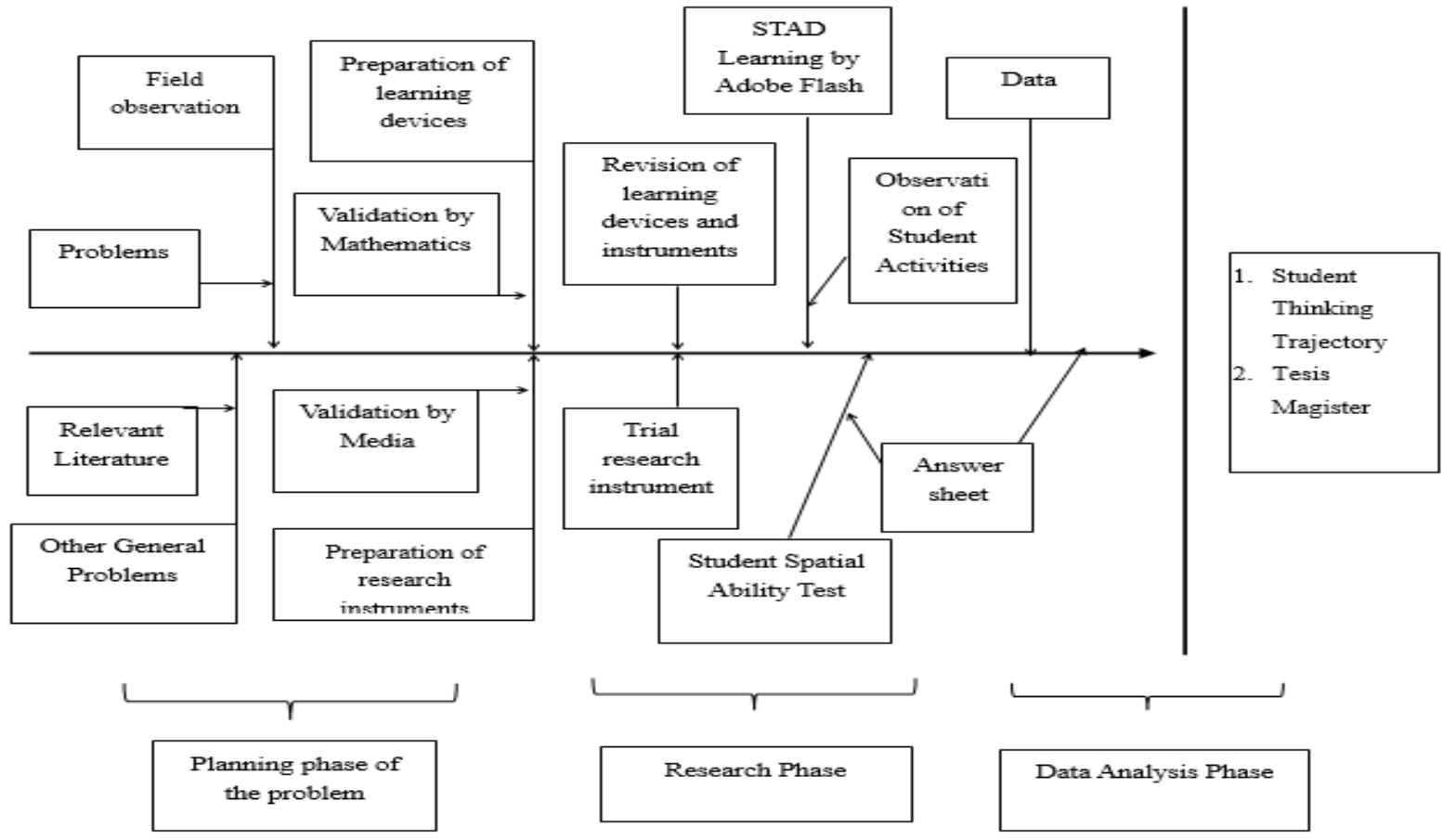

Picture 1 Fishbone Research Phase Diagram 
The process of developing the media through an analysis phase that includes problem analysis and needs analysis. The second stage is the design phase which includes making flowcharts, storyboards, and interface designs. Then the third stage is the stage of media development which includes material collection, product making, code writing, alpha testing, revision, and beta testing. This product development utilizes Adobe flash software, using the Action Script 3.0 programming language. The results of this multimedia development are in the form of an android application in the * .apk format. with the specifications of the device to run it as follows: (1) Operating systems Android 2.2 (froyo) or newer, (2) RAM 225 or greater, (3) screens with a resolution of 4 inches or larger.

\subsection{Research and Early Data Collection (Define)}

This initial stage is usually called needs assessment. The initial research and data collection was conducted to determine the material and analyze the needs used as the basis for product preparation. This step is done to determine the material and needs analysis in the preparation of the product to be developed. The material taken in this study is to Build Flat-Side Space in the second semester of the Cube and Cuboid class VIII.

The selection of this material is based on several reasons, namely this material is the basis of geometry material and material adjustments in the teaching and learning process that is taking place in the field with the time of research. So that the research process does not interfere too much with classroom learning activities. After determining the material developed, the researcher conducted a needs analysis. Needs analysis is done through interviews with one of the mathematics subject teachers at MTs Negeri 1 Model Medan to find out the spatial abilities of students to be studied. Based on the results of the interview, it can be concluded that there are still many students who find it difficult to solve spatial concepts. Sometimes there are also students who lack focus in learning, especially if the learning process is monotonous, only focusing on the teacher.

Based on the preliminary study above, the researcher plans to introduce new innovations by utilizing computer / laptop facilities through the development of adobe flash-assisted STAD-based mathematics learning media that will help students improve students' partial abilities through material Build Flat-Side Space on Cubes and Cuboid. Furthermore, media development research will be held to improve the spatial abilities of students, Mathematics Teachers at Medan 1 MTs Negeri 1, Ms. Ummi Salamah, S.Pd, giving researchers in class VIII-11 as a media development class.

2.3.1. Planning (Design)

After collecting data and analyzing needs, the next step is to make a plan. There are several stages in planning development of Adobe Flash-assisted STAD-based mathematics learning media. The planning scheme is as follows:

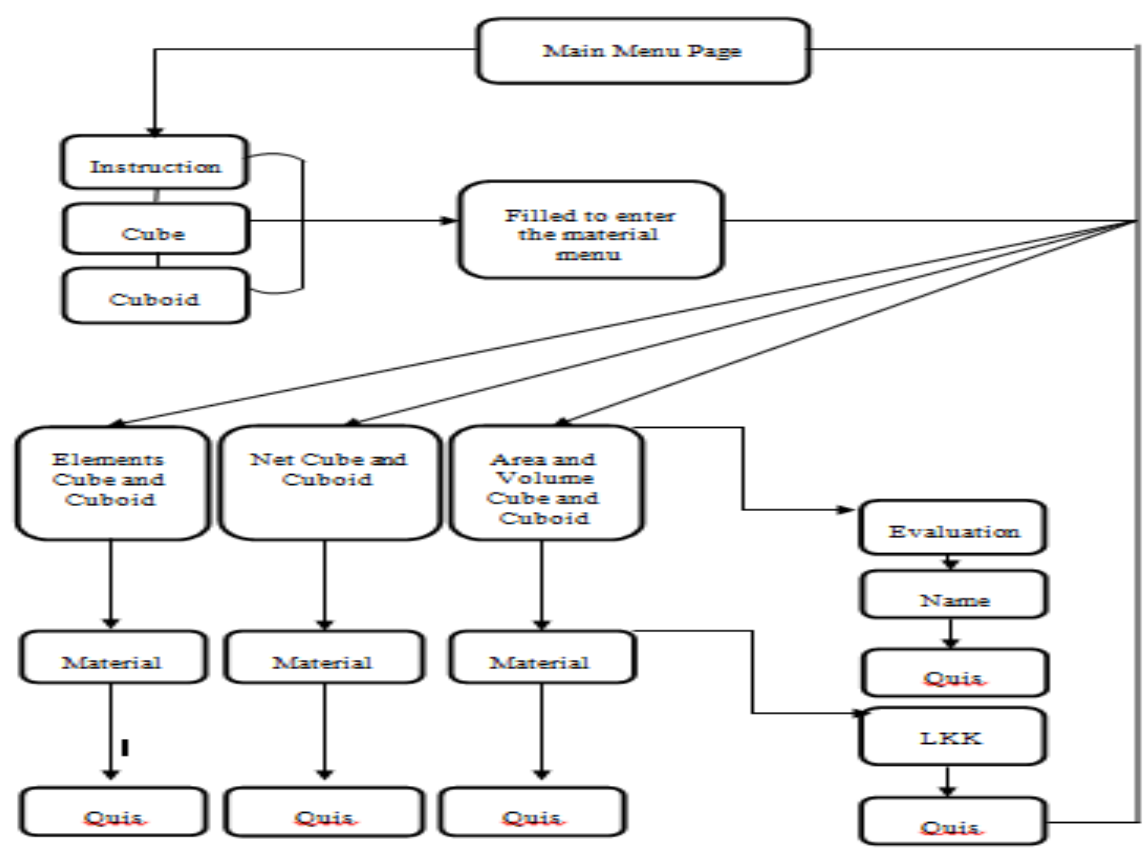

Figure 2. Flowchart

With the existence of mathematics learning media based on STAD assisted by Adobe Flash, it is hoped that it can be a solution for the learning and learning process of Building Flat-Side Space in Cubes and Cuboid so that it can improve students' spatial abilities in this material. Media learning mathematics with Adobe Flash-assisted STAD contains: images, text, videos, learning resources, and instructions for use so that it is easier for students to absorb the learning material provided compared to not using learning media. 


\subsubsection{Presentation of Products for Developing Learning Media}

The media LKPD is a place to write down the answers and procedures that have been obtained in groups based on the problems found in the LKPD that refer to the learning media that has been displayed. On LKPD work instructions are provided, a place to write names and answers to LKPD questions. The

following is a visual display of one of the learning media and also the LKPD used by the students in each of the 2 pictures:

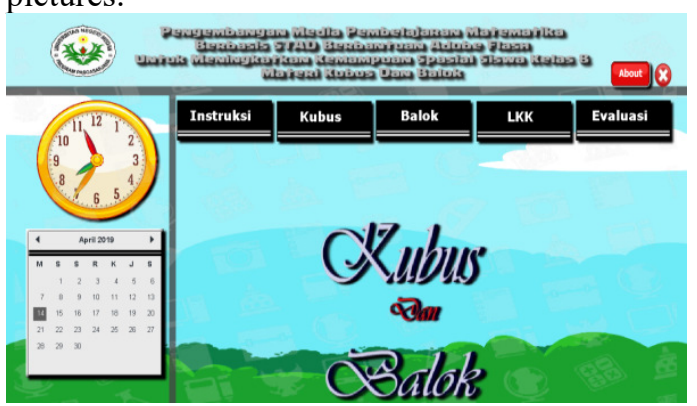

Figure 2. (a)

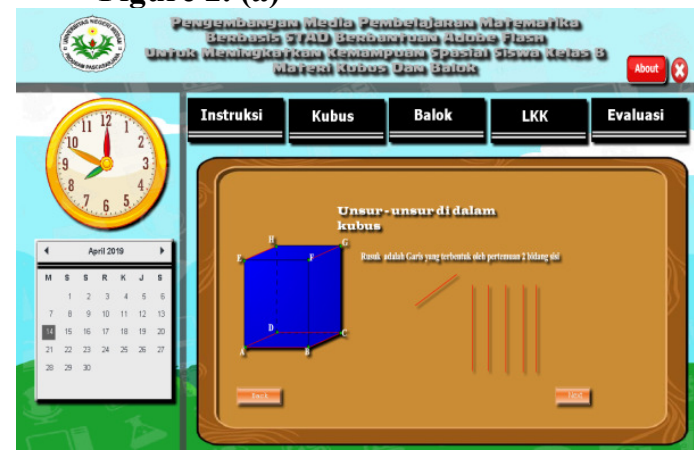

Figure 2. (c)

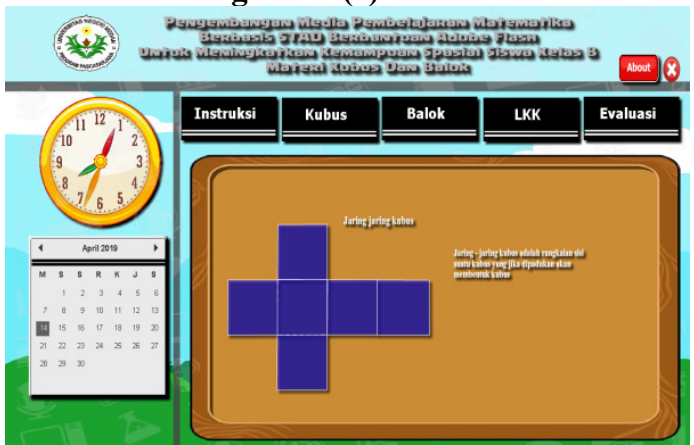

Figure 2. (e)

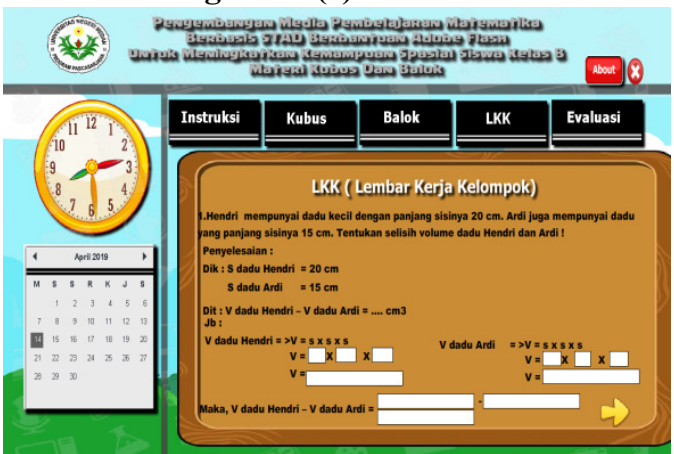

Figure 2. (g)

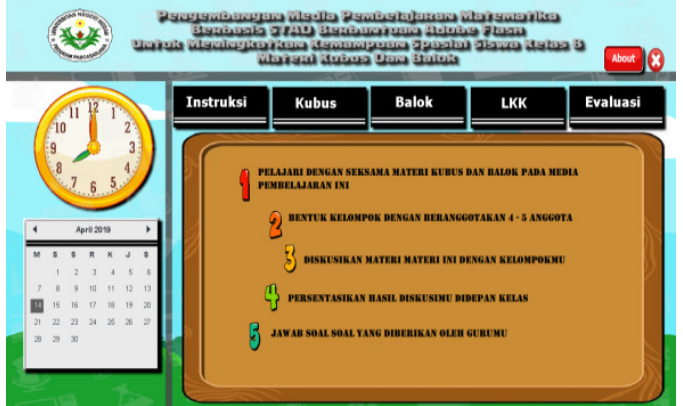

Figure 2. (b)

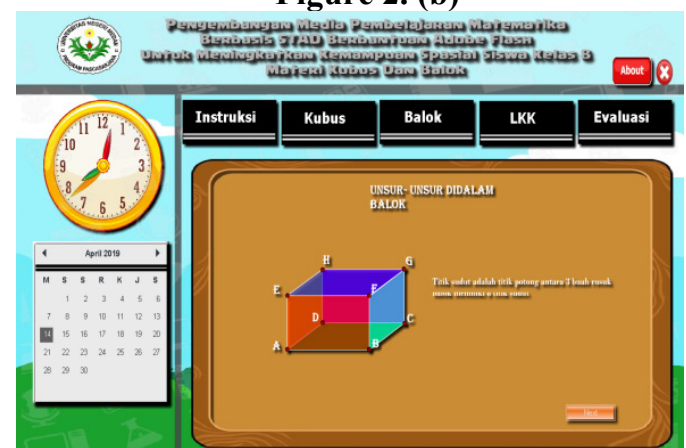

Figure 2. (d)

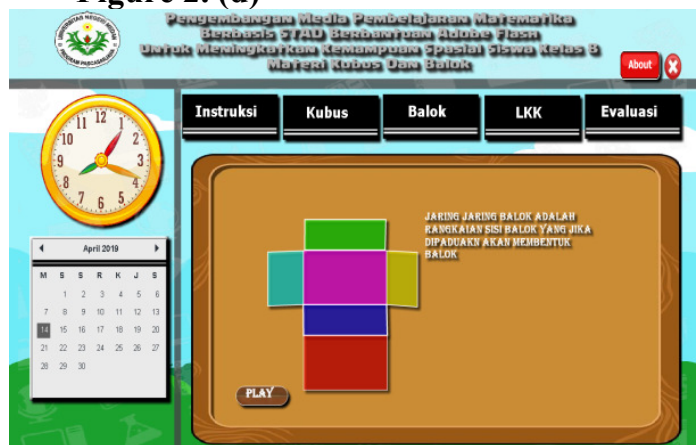

Figure 2. (f)

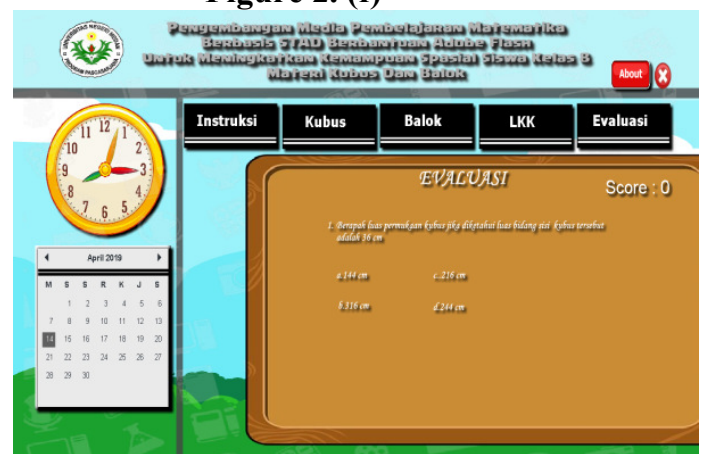

Figure 2. (h)

The learning application process that uses Adobe Flash is shown in Figure 2. In Figure 2. (a) displays the cover material of cubes and beams. The teacher explains to students every use of the menu button on the screen. Figure 2. (b) is the display of instructions from STAD learning, the teacher explains the steps in implementing classroom learning in accordance with the STAD learning. Figure 2. (c) display of the elements of the cube, students can pay attention to the elements of the cube carefully and students more easily understand the results of 
the video. While image 2. (d) the appearance of the beam elements, students can pay attention to the elements of the beam carefully and students are more easily understood from the results of the video. Figure 2. (e) displaying video webs of cubes, students can pay attention to the net of the cube carefully and students understand more easily from the results of the video. While Figure 2. (f) displays videos of beam webs, students can pay close attention to the nets of the beams and students understand more easily from the results of the video. Furthermore, figure 2 . (g) is the appearance of the LKPD on LKK cube and beam material, students can answer these questions in groups. While image 2. (h) is the appearance of the LKPD on the evaluation of cube and beam material, students can answer these questions after studying the previous cube and beam material and working in groups.

\section{Findings}

3.1. Feasibility of Mathematics Learning Multimedia

To assess product feasibility, feasibility validation is carried out by material experts and media experts. Experts provide advice on products that are developed if it is deemed less feasible. For product testing, product testing is conducted on students of class VIII-11. In this trial, instruments were used by using a 1-4 scale scoring score for material experts and media experts while for students using a scale of 1 to 4 according to the guidelines that had been set previously. Based on the results of the feasibility assessment of experts and students are described as follows:

\subsection{Media expert}

Assessments carried out by media experts include assessments of navigation, ease, writing, and aspects of appearance to assess products that have been developed. From the results of the assessment revisions were made according to suggestions. The results of the media expert's assessment found a percentage score of media feasibility from the navigation aspect of $95 \%$ with a very feasible category, $84 \%$ facilitation aspect with a very decent category, $80 \%$ writing aspect with a very feasible category, and $78.58 \%$ display aspect with decent category. Based on the scores of the four aspects, the final score of media feasibility was $84.34 \%$. Thus, the learning media feasibility category can be said in the "Very Worthy" category to be used.

\subsection{Material expert}

Assessment carried out by material experts includes assessments of aspects of learning and material aspects whether in accordance with the material being taught or not. From the results of the assessment revisions were made according to suggestions. The results of the assessment of instructional media by material experts, from the learning aspect of $70 \%$ with a feasible category and material aspects of $71 \%$ with a feasible category, so that the final percentage of eligibility obtained $70.5 \%$. Thus the media of mathematics learning in the "Eligible" category is used.

\subsection{Students}

Assessment by students includes aspects of ease, motivation, attractiveness, and usefulness. From the assessment of these aspects, the percentage score of feasibility obtained from facilitation aspects was $93.7 \%$ with very feasible categories, motivation aspects $92.2 \%$ with very decent categories, attractiveness aspects $91.7 \%$ with very feasible categories, and compliance aspects of $94,2 \%$ with a very decent category, so that the final percentage is $92.9 \%$. Thus based on it can be said that learning media in the category "Very Worthy" to be used in helping students learn Mathematics. Thus according to students the media made easy to use, can motivate learning, be interesting, and useful or help students in learning.

\subsection{Results of Student Spatial Ability After Using STAD-Based Mathematics Learning Media}

From the results of the use of the media it is known that the percentage of students who meet the completeness score at the pre-test is $34 \%$ or as many as 15 children meet the KKM, while at the post-test $86 \%$ or as many as 38 children meet the minimum completeness criteria. This shows that the application of learning media has a positive impact on the completeness of students' spatial abilities.

\section{Conclusion}

The conclusions that can be drawn from the research conducted are as follows:

1. The results of the product feasibility test are as follows:

a. The results of the media expert's assessment found a percentage score of media feasibility from the navigation aspect of $95 \%$, facilitation aspects of $84 \%$, writing aspects of $80 \%$, and display aspects of $78.58 \%$. Based on the score of the four aspects, the final score of media feasibility was $84.34 \%$ with the category "Very Worthy".

b. Assessment of learning media by material experts, from the learning aspects of $70 \%$ and material aspects by $71 \%$, so that the percentage of final feasibility was obtained by $70.5 \%$ with the category "Eligible".

c. The results of the assessment by students were from facilitation aspects of $93.7 \%$, motivation aspects $92.2 \%$, 
attractiveness aspects $91.7 \%$, and aspects of saving $94.2 \%$, so the final percentage was $92.9 \%$ with the category "Very Worthy.

2. From the results of the spatial ability of students from the use of cooperative-based media type STAD it is known that the percentage of students who meet the completeness score at the pre-test is $34 \%$, while at the posttest it is $86 \%$. Thus the application of learning media can be said to improve the spatial ability of students.

\section{References}

Erdoğan, Y., \& Dede, D. 2015. Computer assisted project-based instruction: The effects on science achievement, computer achievement and portfolio assessment. International Journal of Instruction, 8(2), 177-188. https://doi.org/10.12973/iji.2015.8214a

Kosa, T. \& Karakus, F. 2010. Using Dynamic Geometry Software Cabri 3D for Teaching Analytic Geometry. Procedia - Social and Behavioral Sciences. 2 (2).

Nieveen. 1999. Principles and Method of Development Research. London.Dlm. van den Akker, J., Branch, R.M., Gustafson, K., Nieveen, N., \& Plomp, T. (pnyt.)”. Design approaches and tools in educational and training. Dordrecht: Kluwer Academic Publisher.

Noviyarti E., Marzal J., \& Rohati. 2015. Pengembangan Media Pembelajaran Menggunakan Adobe Flash dan Autoplay Media Studio dalam Pembelajaran Berbasis Inkuiri pada Materi Garis dan Sudut Sekolah Menengah Kelas VII.Edumatica : Jurnal Pendidikan Matematika, 4 (2), ISSN :2088-2157.

Pratidhina.E, Pujianto, \& Sumardi. Y. 2019. Developing Computer Program as a Learning Resource on Gas Law Topics for High School Students. International Journal of Instruction, 12(2), 133-146. https://doi.org/10.29333/iji.2019.1229a

Putri, S, K,. Hasratuddin,. \& Syahputra, E,. 2019. Development of Learning Devices Based on Realistic Mathematics Education to Improve Students' Spatial Ability and Motivation. International Electronic Journal of Mathematics Education. 14(2), 393-400. https://doi.org/10.29333/iejme/5729

Sinurat M., Syahputra E., \& Rajagukguk W., 2015. Pengembangan Media Pembelajaran Matematika Dibantu oleh Program Flash untuk Meningkatkan Kemampuan Matematika Siswa Sekolah Menengah. Jurnal Tabularasa, 12(2), 154-170. Medan:PPs UNIMED.

Syahputra E., 2013. Meningkatkan Kemampuan Spasial Siswa Dengan Pembelajaran Matematika Realistis. Jurnal Cakrawala Pendidikan, November 2013, Th. XXXII, (3).

Sari D.P, Syahputra E., \& Surya E., 2018. An Analysis of Spatial Ability and Self-efficacy of Students in Cooperative Learning by Using Jigsaw at SMAS Muhammadiyah 8 Kisaran. American Journal of Educational Research, 2018, 6(8), 1238-1244.

Subroto. 2016. Pengaruh Pendekatan Apos-Modified pada Kemampuan Abstraksi Matematika dalam Struktur Aljabar Dasar 1. Jurnal FKIP Unswagati Press, Februari 2016. 2(1), 252-264.

Sugiyono. 2010. Metode Penelitian Pendidikan Kuantitatif, Pendekatan Kualitatif dan $R$ \& D. Bandung: Alfabeta.s 